\title{
Producing Research Entrepreneurs Can Use
}

\author{
Jon Eckhardt (University of Wisconsin-Madison)
}

KEYWORDS: Entrepreneurship, Research Methods, Higher Education.

Entrepreneurs often perceive a gap between research conducted in academia, and the practical problems that they face when building companies. As recognized by the AACSB - the accrediting body for Business Schools - this research/practice divide is not unique to the field of entrepreneurship. The research/practice divide likely exists across most fields of study within research-based business schools.

Fortunately, scholars are experimenting with different approaches to bridge the research/practice divide, and EIX has been covering this topic. Below is a list of our articles to date on this issue. We welcome more submissions on this topic. If you are interested, please click on the "CONTRIBUTE AN ARTICLE" button at the top of our site.

Today's Entrepreneurs Can Inform Tomorrow's Research(https://eiexchange.com/content/todaysentrepreneurs-can-inform-tomorrows-resear)

Connecting Business Research to Practice (https://eiexchange.com/content/126-connecting-busine ss-research-to-practice?search=connecting $\% 20$ busines s\%20research)

Driving Impactful Research: A Conversation with Charles Dhanaraj (https://eiexchange.com/content/Driving-impactful-resea rch-a-conversation-with-charles?search=dhanaraj)

Researchers: Are You Asking the Wrong Questions? (https://eiexchange.com/content/Researchers-are-youasking-the-wrong-questions?search=dhanaraj)

Social Entrepreneurship Deserves Better Research (https://eiexchange.com/content/74-social-entrepreneur ship-deserves-better-research?search=social\%20entre preneurship\%20deserves)

Entrepreneurship Research: Which Trails to Blaze Next (https://eiexchange.com/content/269-entrepreneurship-r esearch-which-trails-to-

blaze?search=which\%20trails\%20to\%20blaze)

James Wetherbe: How Consulting Connects Colleges to the Real World (https://eiexchange.com/content/360-James-Wetherbehow-consulting-connects-

colleges?search=how\%20consulting\%20connects)

An Interview with David Teece, a Practicing Business Intellectual

(https://eiexchange.com/content/349-interview-withdavid-teece-practicing-business-i?search=teece)

Minefield or Opportunity: How to Work Constructively with Universities

(https://eiexchange.com/content/118-minefield-or-oppor tunity-how-to-work-constructiv?search=minefield)

'Champions' Make Diverse Spinoff Teams More Successful (https://eiexchange.com/content/379-champions-makediverse-spinoff-teams-mor?search=Champions)

Additional Search Terms: how business and universities can work together, business and university partnerships, entrepreneurship research, best practices, entrepreneurship schools 